\title{
GRAIN QUALITY AND STATUS OF OATS (Avena sativa L.) DURING STORAGE
}

\author{
S. Rakić ${ }^{1}$, S. Janković ${ }^{2}$, M. Krivokapić ${ }^{1}$, R. Jovanović ${ }^{2}$ J. Ikanović \\ ${ }^{1}$ University of Belgrade, Faculty of Agriculture, 6 Nemanjina St., Belgrade 11081, Serbia. \\ ${ }^{2}$ Institute for Science Application in Agriculture, 68b Bulevar Despota Stefana, Belgrade 11000, \\ Serbia. \\ *Corresponding author: Sveto Rakić, sveto@agrif.bg.ac.rs \\ Original scientific paper
}

Abstract: The purpose of this study has been to determine the effect of storage on grain quality of three oat cultivars selected in Serbia - Dunav, Vrbas and NS Tara. Freshly harvested oats were stored at the temperature of $25 \pm 2{ }^{\circ} \mathrm{C}$ for 12 and 20 months. There was a significant decrease in the volume mass (458.4 to $408.9 \mathrm{~kg} / \mathrm{m}^{-3}$ ) and the absolute mass of grains (26.6 to $24.2 \%$ ) during the storage. The germination potential of the grains decreased over time (96.2-94.1\%). The changes in the acid degree values (3.77-3.99 $\mathrm{ml} 1(\mathrm{Na} \mathrm{OH} / 100 \mathrm{~g})$ are highly significant $(\mathrm{p}<0.01)$. Initially, the $\mathrm{pH}$ level of the fresh samples was 6.2 , and it decreased to 5.8 after 20 months. Genotypes and volume mass have great effect on storage duration $\left(\eta^{2}=0.8130 \eta^{2}=0.7621\right.$ and $\left.\eta^{2}=0.6780\right)$. The interaction between the studied factors did not show statistically significant effects on the change in germination of oat grains ( $>0.05)$. What mostly affects an increase in the acid degree value of oat grains is storage duration, followed by a genotype and the interaction between these two factors. The studied oat genotypes show no significant differences in glassiness ( $\mathrm{p}>0.05$ ).

Key words: oat, storage effect, physicochemical and biological traits

\section{Introduction}

Oat grains are used in various foods in many parts of the world for their naturally high amount of valuable nutrients, such as soluble fibres, proteins, unsaturated fatty acids, vitamins, minerals and phytochemicals (Flander et.al, 2008). A high lipid content (Eggum and Gullord 1983; Peterson, 2002) and the form of carbohydrate and protein compounds in oat grains have a negative effect on rheological traits, which limits their use. Oat flakes are used instead. Important components of oat grain cells are $\beta$-glucan (Ren et al., 2003), fibres and other secondary metabolites, which are health-promoting (Biorklundet.al, 2005). Oat proteins do not have the unique viscoelastic traits of wheat gluten and its products result in lower quality and lower bread volume (Flander et.al, 2007, 2008). Due to its chemical composition, nutritional and functional traits, oat grains have a significant 
utilization value for humans and animals (Peltonen-Sainio et al., 2004; Peterson, 2004). Some studies on the use of cereal grains (Stanković et. al, 2011) as sources of fast fermenting energy have been conducted (Vasilachil et.al, 2010). There are various studies on effects of temperature, air humidity and storage duration on significant losses of nutrient compounds in grains (Shah et.al, 2002) available in literature. Grains can be stored for a short and long period of time (one year or more). Two most important factors for proper storage are humidity and temperature. Nowadays, grains are stored under conditions of low humidity (below the critical point), airtight conditions, or at temperatures so low that stop all biological functions of grains (Žeželj, 1995). The object of one study was also a change in physical traits of grains during storage (Kent and Evers, 1994). A study (Rehman, 2006) on detecting the effects of storage conditions on nutrient traits in wheat, maize and rice collected the data that showed significant changes in physical and chemical parameters of the tested samples. Those changes in physiochemical traits of oat grains during storage are crucially important from the aspect of biochemistry and nutrition.

The goal of these studies was to assess the effect of storage duration on some physical, biological and chemical traits of oat grains.

\section{Materials and Methods}

The studied oat grain genotypes Dunav, Vrbas and NS Tara are commercial cultivars selected at the Institute of Field and Vegetable Crops in Novi $\mathrm{Sad}$, and listed in the Register of cultivars of the Republic of Serbia. The material for the analysis was produced in 2010 at Rimski Šančevi trial field, with the application of regular cropping practices for oat production. The laboratory samples were taken from freshly harvested grains, with the use of standard grain sampling methods (ISO 24333:2009). All the samples were protected from insects, without using any chemicals. Approximately $500 \mathrm{~g}$ of each tested grain sample with 11-13\% moisture were stored in closed plastic containers of the same volume. These samples were labelled and stored under controlled environmental conditions, at the temperature of $25 \pm 2{ }^{\circ} \mathrm{C}$ for 12 to 20 months. At the end, three containers were randomly taken, and their content was mixed and tested for quality and status. In order to test the quality and the status of the samples, some physical, biological and chemical traits were determined. Physical traits - absolute mass, volume mass, glassiness - were determined according to Kaluđerski and Filipović (1998). During germination tests, seed quality is measured directly as the ability of the seed to germinate under optimal germination conditions of temperature, moisture and light (ISTA, 1996). The titratable acidity as a chemical trait was expressed as sodium hydroxide required neutralizing the acids in a $100 \mathrm{~g}$ sample, using phenolphthalein as an indicator $(A O A C, 1990)$. The another chemical trait - $\mathrm{pH}$ value was determined in a filtrate of $2 \mathrm{~g}$ powdered sample $(1 \mathrm{~mm}$ mesh size $)$ in $20 \mathrm{ml}$ of 
distilled water with a pH meter glass electrode (Hanna, HI83141, Instruments USA). Homogeneity of variance was determined with the Levene's test to draw objective conclusions regarding the effects of the studied factors on the oat traits, and to apply parametric tests (ANOVA and LSD-test).

Testing differences between genotypes and storage duration, and their interaction was conducted with the variance analysis of a two-factorial trial model (ANOVA) and then LSD-test for the risk level of 5\% and 1\% (Hadživuković, 1977). The importance of each factor and interactions between them were determined with the partial eta-squared coefficient, and classified according to Cohen (Cohen, 1988). The experimental data were processed with STATISTICA 10 for Windows (StatSoft).

\section{Results and Discussion}

The results of the Levene's test indicated that only the sample variances of volume mass were not homogeneous (Table 1). Since not all the traits were homogenous, only statistically significance for an upper risk level (1\%) was observed.

Table 1. Levene's test

\begin{tabular}{|c|c|c|}
\hline Trait & F & p-level \\
\hline Glassiness and flouriness & 2.609 & 0.0515 \\
\hline Acid degree value & 2.059 & 0.0967 \\
\hline Volume mass & 11.886 & 0.0000 \\
\hline Germination & 2.592 & 0.0623 \\
\hline Absolute mass & 1.570 & 0.2027 \\
\hline $\mathrm{pH}$ & 2.207 & 0.0720 \\
\hline
\end{tabular}

The status of the traits of oat grains depending on storage duration is shown in the Table 2 . The $\mathrm{pH}$ in oat grains varied during the experiment, along with the storage duration and the genotypes. Samples variability is very small and it shows great homogeneity both by the time intervals $(\mathrm{CV}<1.32 \%)$, and by the genotypes $(\mathrm{CV}<2.78 \%)$. The longer storage time was the lower $\mathrm{pH}$ was. The F-test indicated statistically significantly different $\mathrm{pH}$ values obtained in different time periods $\left(\mathrm{Fuz}=471^{* *}\right)$. The $\mathrm{pH}$ of fresh samples, therefore, was statistically higher than the ones after 12 and 20 months of storage $(p<0.01)$. The samples of Dunav genotype had significantly higher $\mathrm{pH}$, compared to NS Tara and Vrbas genotypes. The interactions of the tested factors (storage duration and genotype) showed statistical significance $\left(\mathrm{Fuz}=6^{* *}\right)$. The values of the partial eta-squared coefficients $\left(\eta^{2}=0.9812, \eta^{2}=0.8732\right.$ and $\left.\eta^{2}=0.5880\right)$ showed great effects of the genotypes and the storage duration.

The storage duration had no significant effect on the change in glassiness of oat grains that could be treated as flouriness. Variability of the studied samples 
was very low (during storage $\mathrm{CV}<1.20 \%$, and $\mathrm{CV}<1.24 \%$ for the genotypes). The differences between the observed time intervals were not statistically significant. Since the interaction between the factors (storage duration and genotype) did not show a significant effect on changes in glassiness and flouriness of oat grains ( $>0.05)$ the partial eta-squared coefficient analysis is not relevant to those two factors.

Table 2. Effect of storage duration (months) (A) and genotypes (B) on the tested oat traits

\begin{tabular}{|c|c|c|c|c|c|}
\hline Factor & $\mathrm{pH}$ & $\begin{array}{c}\text { Glassiness } \\
(\%)\end{array}$ & $\begin{array}{c}\text { Volume mass } \\
\left(\mathrm{kg} / \mathrm{m}^{-3}\right)\end{array}$ & $\begin{array}{c}\text { Germination } \\
(\%)\end{array}$ & $\begin{array}{c}\text { Absolute } \\
\text { mass }(\mathrm{g})\end{array}$ \\
\hline$(\mathrm{A})$ & & & & & \\
0 & $6.2^{\mathrm{a}} \pm 0.027$ & $24.2^{\mathrm{a}} \pm 0.097$ & $458.4^{\mathrm{a}} \pm 7.921$ & $96.2^{\mathrm{a}} \pm 0.862$ & $26.6^{\mathrm{a}} \pm 0.752$ \\
12 & $6.0^{\mathrm{b}} \pm 0.012$ & $24.1^{\mathrm{a}} \pm 0.037$ & $440.3^{\mathrm{b}} \pm 8.064$ & $96.3^{\mathrm{a}} \pm 1.000$ & $25.4^{\mathrm{b}} \pm 0.630$ \\
20 & $5.8^{\mathrm{a}} \pm 0.017$ & $24.1^{\mathrm{a}} \pm 0.055$ & $408.9^{\mathrm{c}} \pm 9.997$ & $94.1^{\mathrm{b}} \pm 0.564$ & $24.2^{2^{\mathrm{a}} \pm 0.631}$ \\
& & & & & \\
\hline (B) & & & & & \\
$\begin{array}{c}\text { Dunav NS } \\
\text { Tara }\end{array}$ & $6.1^{\mathrm{a}} \pm 0.057$ & $24.2^{\mathrm{a}} \pm 0.100$ & $431.4^{\mathrm{b}} \pm 6.883$ & $96.4^{\mathrm{a}} \pm 0.709$ & $23.2^{\mathrm{c}} \pm 0.218$ \\
Vrbas & $5.0^{\mathrm{b}} \pm 0.040$ & $24.1^{\mathrm{a}} \pm 0.024$ & $459.3^{\mathrm{a}} \pm 6.882$ & $93.8^{\mathrm{b}} \pm 0.564$ & $27.8^{\mathrm{a}} \pm 0.365$ \\
\hline
\end{tabular}

*Means in columns followed by the same letter are not significantly different according to Fisher's protected LSD values $(\mathrm{P}=0.05)$

A dispersion of the samples that followed the values of oat grain volume mass was not emphasized, so during storage time $\mathrm{CV}<7.33 \%$, that was $\mathrm{CV}<9.50 \%$ for the analysed genotypes. The longer storage time is the lower volume mass is. At the beginning, the volume mass was $458.4 \mathrm{~kg} / \mathrm{m}^{-3}$, after a year it decreased to $440.3 \mathrm{~kg} / \mathrm{m}^{-3}$, and after 20 months the volume mass was $408.9 \mathrm{~kg} / \mathrm{m}^{-3}$. Once determined, the average volume mass significantly decreased over time. The differences between the time intervals were statistically significant $(p<0.05)$. The volume mass of NS Tara grains was higher than the volume mass of the other two genotypes (Vrbas and Dunav), $\mathrm{p}<0.05$. The volume masses of Dunav and Vrbas had no statistical differences ( $p>0.05)$. The changes in the volume mass were also affected by the interaction of the studied factors $(p<0.05)$. The partial eta-squared coefficients also showed a high effect of genotypes and storage duration on changes in volume mass of oat grains (Table 4). This shows that not only do storage duration and genotypes have significant effect on changes in volume mass, but their effect is also very high according to the Cohen's classification $\left(\eta^{2}=0.8130\right.$ $\eta^{2}=0.7621$ and $\eta^{2}=0.6780$ ). The variability of the tested samples was not distinctive between the storage time intervals, as well as the genotypes $(\mathrm{CV}<3.3 \%)$. There was no significant changes in germination in the first year of storage (at the beginning it was $96.2 \%$, and at the end $96.3 \%$ ), but in the second year there was a significant decrease, so that the germination was $94.1 \%$ after 20 months of storage. Thus the germination in the second year was significantly lower than in the first year $(\mathrm{p}<0.01)$. The germination between the oat grains of Dunav and Vrbas varieties did 
not differ, yet it was significantly higher than the one of NS Tara genotype (93.8\%, $\mathrm{p}<0.01)$. The interactions between the studied factors had no significant effect on changes in the germination ( $\mathrm{p}>0.05$ ). The results of previous studies (Wilhelmson et al, 2001; Tian et al, 2010) on physical and chemical changes in oat have shown significant changes that occur during germination, having positive effects on nutritive traits of samples. The partial eta-squared coefficients also showed a very high effect of the genotype and the storage duration on the germination (Table 3). Therefore, not only did the genotypes have a significant impact on changes in oat grains germination, but also their effect was very high according to the Cohen's classification $\left(\eta^{2}=0.3177\right)$, as well as the coefficient of storage duration $\eta^{2}=0,2592$.

The Table 3 also shows a variation in absolute mass, depending on storage duration and oat genotypes. The values of the defined coefficients of variation are $<8 \%$ for storage duration and $<6 \%$ for genotypes, which indicate homogeneity of the samples. The absolute mass of oat grains varied depending on the storage duration. Its value was the highest at the beginning (26.6\%), and it decreased over time, from $25.4 \%$ after a year to $24.2 \%$ after 20 months of storage. Storage duration, therefore, statistically highly affects a decrease in absolute mass of oat grains $(p<0.01)$. The differences in the absolute masses in all time intervals are statistically significant. The absolute mass of NS Tara genotype was statistically higher than the absolute mass of the other two genotypes (Dunav and Vrbas $\mathrm{p}<0.01$ ). The absolute mass of Dunav genotypes was just $23.2 \%$, and it was statistically lower than the absolute mass of the other two genotypes. The partial eta-squared coefficients indicate that storage time and oat genotypes, as well as their interaction, greatly affect changes in absolute mass of oat grains. The coefficients were as follows: $\eta^{2}=0.9506, \eta^{2}=0.9853$ and $\eta^{2}=0.7146$. According to the Cohen's classification, that is a very high effect. The Figure 1 illustrates changes in the acid degree value of oat grains, depending on storage time. The acid degree value changed with the storage duration but it also changed with the different genotypes. The selected samples showed homogeneity (storage duration: $\mathrm{CV}<4 \%$, genotypes: $\mathrm{CV}<9 \%$ ). The acid degree value increased with an increase in the storage duration. At the beginning, the acidity was $3.37 \mathrm{ml} 1(\mathrm{Na} \mathrm{OH} / 100 \mathrm{~g}$, after a year it came to $3.76 \mathrm{ml} 1(\mathrm{Na} \mathrm{OH} / 100 \mathrm{~g}$, whilst after 20 months of storage, the acid degree value was $3.99 \mathrm{ml} 1(\mathrm{Na} \mathrm{OH} / 100 \mathrm{~g}$. Those differences are statistically very significant $(\mathrm{p}<0.01)$. Furthermore, the acid degree values in the selected genotypes also differed $(\mathrm{p}<0.01)$. The highest acid degree value had Vrbas genotype, followed by Dunav and NS Tara genotypes. The interaction between the factors also affected differences in acid degree values $(\mathrm{p}<0.01)$. These results are in accordance with a previous study (Rehman, 2006) that determined an increase in acid degree values of maize, wheat and rice grains, what can be a result of an increase in free fatty acids and phosphates, and the presence of by-products (Maillard reactions) in grains stored at higher temperatures (Gardner, 1979). 


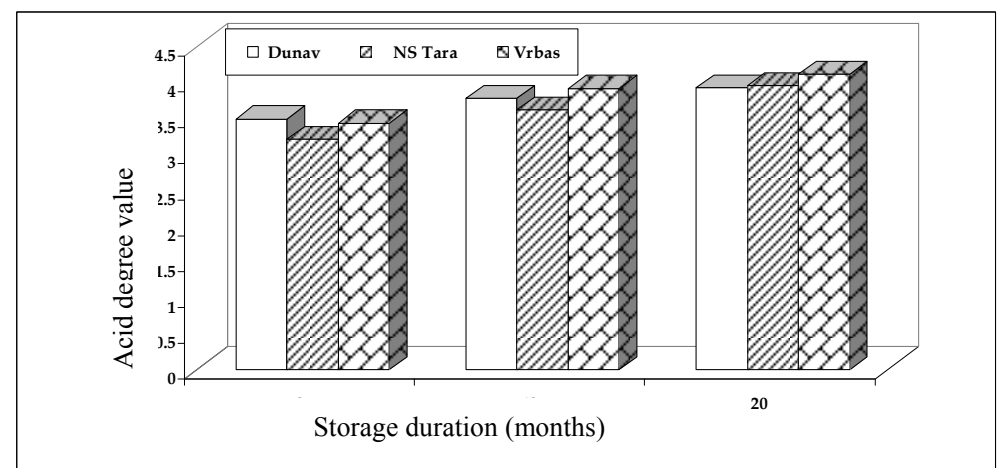

Figure 1. Acid degree value according to genotypes and storage duration of oat grains

Not only do genotypes, storage duration, and their interaction statistically have a very significant effect on the acid degree value, but their impact is also high, as you can see from the partial eta-squared coefficients $\left(\eta^{2}=0.9764, \eta^{2}=0.8464\right.$ and $\eta^{2}=0.6907$ ) (Table 3 ). They hence show that an acid degree value increase is mostly affected by storage duration, then by genotypes and the interaction of the factors.

Table 3. Partial eta-squared coefficients ( $\eta 2$ )*

\begin{tabular}{|l|c|c|c|}
\hline \multicolumn{1}{|c|}{ Trait } & Storage duration & Genotype & Interaction \\
\hline Glassiness & 0.0890 & 0.2642 & 0.2787 \\
\hline Acid degree value & 0.9764 & 0.8464 & 0.6907 \\
\hline Volume mass & 0.8130 & 0.7621 & 0.6780 \\
\hline Germination & 0.2592 & 0.3177 & 0.2725 \\
\hline Absolute mass & 0.9506 & 0.9853 & 0.7146 \\
\hline $\mathrm{pH}$ & 0.9812 & 0.8732 & 0.5880 \\
\hline
\end{tabular}

Partial eta-squared coefficients calculated based on the data from the analysis of variance table

\section{Conclusion}

The storage duration at the constant temperature of $25 \pm 2{ }^{\circ} \mathrm{C}$ had a negative effect on quality and status of oat grains. The study determined a significant decrease in volume and absolute mass and a gradual decrease in germination potential, which was still quite high (over 90\%). The storage duration did not significantly affect glassiness and flouriness. Changes in the acid degree values $(3.7$ - $3.9 \mathrm{ml} 1(\mathrm{Na} \mathrm{OH} / 100 \mathrm{~g})$ and $\mathrm{pH}(6.0$ - 5.8) were significant, which was expected considering those traits show a status freshness of grains. The grain kept its functional traits. Based on the presented results, storage under these conditions 
can also be recommended, especially in the cases of exporting the grain in southern parts of the world, where average air temperatures are higher and there are more food demands. In the following period, the scope of this research should be extended on more detailed studying of the chemical compound of oat grains and their status during storage.

\section{Acknowledgment}

Research was financed by the Ministry of Education, Science and Technological Development of the Republic of Serbia, project TR 31066.

\section{Kvalitet i stanje semena ovsa (Avena sativa L.) tokom skladištenja}

S. Rakić, S. Janković, M. Krivokapić, R. Jovanović, J. Ikanović

\section{Rezime}

Ispitivan je uticaj skladištenja na kvalitet i stanje semena ovsa za tri sorte (Dinav, Vrbas i NS Tara) koje su selekcionisane u Srbiji. Svže požnjeven ovas je uskladisten na $25 \pm 2{ }^{\circ} \mathrm{C}$ na 12 i 20 meseci. Zabeležen je značajan pad vrednosti zapreminske $458.4-408.9 \mathrm{~kg} \mathrm{~m}^{-3} \mathrm{i}$ apsolutne mase 26.6 - $24.2 \%$ tokom skladištenja semena ovsa. Sa dužinom vremena skladištenja smanjivalo se biološko svojstvo semena na sposobnost klijavosti 96.2-94.1\%. Promene kiselinskog stepena $(3.77-3.99 \mathrm{ml} 1(\mathrm{Na} \mathrm{OH}) / 100 \mathrm{~g})$ su statistički veoma značajne $(\mathrm{p}<0.01)$. $\mathrm{pH}$ vrednost svežih uzoraka semena je bila 6,2 a nakon 20 meseci 5,8. Dužina skladistenja nije značajno uticala na svojstvo staklavosti. Genotip i zapreminska masa imaju visok uticaja na dužinu skladištenja $\left(\eta^{2}=0.8130 \quad \eta^{2}=0.7621\right.$ i $\eta^{2}=0.6780$ ). Interakcija ispitivanih faktora nije ispoljila statistički značajan uticaj na promenu stepena klijavosti semena ovsa $(\mathrm{p}>0.05)$. Dužina skladištenja semena ovsa najviše doprinosi porastu vrednosti kiselinskog stepena, a nešto manje genotip, kao i interakcija ovih faktora. Testirani genotipovi ovsa nemaju značajne razlike u pogledu staklavosti semena $(\mathrm{p}>0.05)$.

\section{References}

AOAC (1990): Official methods of analysis (14th ed.). Washington DC, USA: Association of Official Analytical Chemists. 
BIORKLUND M., REES A., MENSINK R.P., ONNING G. (2005): Changes in serum lipids and postprandial glucose and insulin concentrations after consumption of beverages with $\beta$-glucans from oats and barley: a randomized dose-controlled trial. European Journal of Clinical Nutrition, 59, 1272-1281.

COHEN J.W. (1988): Statistical power analysis for the behavioral sciences (2nd edn.).

EGGUM B.O. and GULLARD M. (1983): The nutritional quality of some oat varieties cultivated in Norway Plant Foods for Human Nutrition (Formerly Qualitas Plantarum), 32, 67-73.

FLANDER L., SALMENKALLIO-MARTILLA M., SUORTTI T.K. (2007): Autio Optimization of ingredients and baking process for improved wholemeal oat bread quality LWT-Lebensmittelwissenschaft und-Technologie, 40, 860-870.

FLANDER L., ROUAU X., MOREL M., AUTIO K., SEPPANEN-LAAKSO T., KRUUS K., BUCHERT J. (2008): Effects of laccase and xylanase on the chemical and rheological properties of oat and wheat doughs. Journal of Agricultural and Food Chemistry, 56, 5732-5742.

GARDNER H.W. (1979): Lipid hydro peroxide reactivity with protein and amino acids. Journal of Agricultural and Food Chemistry, 27, 220-228.

HADŽIVUKOVIĆ S. (1977): Planiranje eksperimenata, Privredni pregled, Beograd.

KENT N.L. and EVERS A.D. (1994): Technology of Cereals British Library, ISBN 0080408338.

ISO 24333:2009, Cereals and cereal products - Sampling.

ISTA 1986. ISTA handbook on seed sampling. International Seed Testing Association. Zurich, Switzerland.

KALUĐERSKI G., FILIPOVIĆ N. (1998): Methods of analysis grain quality. University of Novi Sad, Novi Sad

PELTONEN-SAINIO P., KONTTURI M., RAJALA A. (2004): Impact dehulling oat grain to improve quality of on-farm produced feed. I. Hullability and associated changes in nutritive value and energy content. Agricultural and Food Science, 13, $18-28$.

PETERSON, D.M. (2004): Oat - a multifunctional grain. In: Peltonen-Sainio, P., Topi-Hulmi, M. (Eds.), Proceedings, 7th International Oat Conference. Agrifood Research Reports 51. MTT Agrifood Research, Jokioinen, Finland, pp. 21-26 REHMAN Z.U. (2006): Storage effects on nutritional quality of commonly consumed cereals Food Chemistry, 95, 53-57.

REN Y., ELLIS P.R., ROSS-MURPHY S.B., WANG Q., WOOD P.J. (2003): Dilute and semidilute solution properties of $(1 \rightarrow 3),(1 \rightarrow 4)-\beta$-D-glucan, the endosperm cell wall polysaccharide of oats (Avena sativa L.). Carbohydrate Polymers 53, 401-408. 
SHAH W.H., REHMAN Z.U., KAUSAR T., HUSSAIN A. (2002): Storage of wheat with ears. Pakistan Journal of Scientific and Industrial Research, 17, 206209.

STANKOVIĆ S., LEVIĆ J., KRNJAJA V. (2011): Fumonisin $\mathrm{B}_{1}$ in maize, wheat and barley grain in Serbia. Biotechnology in Animal Husbandry 27 (3), 631-641. STATISTICA v. 10.0 (2010): StatSoft. University License, University of Novi Sad, Serbia.

TIAN B., XIE B., SHI J., WUA J., CAI Y, XU T., XUE S., DENG Q (2010): Physicochemical changes of oat seeds during germination. Food Chemistry, 119, $1195-1200$.

VASILACHIL A., POP S., DRAGOMIR C., VLASSA M., FILIP M. (2010): The influence of replacing slow with rapid starch in growing rams' diets on the level of rumen microbial proteosynthesis. Biotechnology in Animal Husbandry 26 (5-6), 339-346.

STATISTICA v. 10.0 (2010): StatSoft. University Licence, University of Novi Sad, Serbia.

WILHELMSON A., OKSMAN-CALDENTEY K.-M., LAITILA A., SUORTTI T., KAUKOVIRTA-NORJ A, POUTANEN K. (2001): Development of a germination process for producing high b-glucan, whole grain food ingredients from oat. Cereal Chemistry, 78, (6), 715-720.

ŽEŽELJ M. (1995): Tehnologija žita i brašna poznavanje čuvanje i prerada žita. Tehnološki fakultet Novi Sad. 